\section{Subirrigation of Quercus rubra Seedlings: Nursery Stock Quality, Media Chemistry, and Early Field Performance}

Mindy L. Bumgarner, K. Francis Salifu, and Douglass F. Jacobs ${ }^{1}$

Hardwood Tree Improvement and Regeneration Center, Department of Forestry and Natural Resources, Purdue University, 715 West State Street, West Lafayette, IN 47907-2061

Additional index words. controlled-release fertilizer, electrical conductivity, media composition, nitrogen, northern red oak, peat

\begin{abstract}
Container seedling production systems for forest tree nurseries are challenged by the need for judicious water consumption. Subirrigation systems may provide an alternative to overhead systems by mitigating water use, yet remain relatively untested for propagation of forest tree seedlings. We evaluated effects of overhead versus subirrigation under varying media (40:60, 60:40, and 80:20 peat:perlite) and fertilization ( 0 or $1.2 \mathrm{~g}$ nitrogen/plant) regimes on nursery development and first-year field performance of northern red oak (Quercus rubra L.) seedlings. Fertilization increased aboveground biomass production and nutrient content, but decreased root dry weight. Relative to overhead-irrigated seedlings, subirrigation increased red oak seedling aboveground biomass production as well as above- and belowground nitrogen content under fertilized conditions. Media had no effect on plant response. Subirrigation increased electrical conductivity $\left(5 \mathrm{dS} \cdot \mathrm{m}^{-1}\right.$ greater) and decreased $\mathrm{pH}$ in the upper media zone ( 0 to $5 \mathrm{~cm}$ from top), whereas the opposite effect was found in the lower zone. Nursery fertilization was associated with reduced field survival and growth, which may have been the result of transplant stress resulting from higher shoot:root. Subirrigated seedlings had greater field diameter growth. Our results suggest that subirrigation could serve as a viable alternative to overhead systems in container propagation of hardwood seedlings.
\end{abstract}

Use of overhead irrigation in container tree seedling production can be wasteful of water resources and should be re-evaluated as social and legal pressures increase to reduce water consumption (Landis and Wilkinson, 2004; Oka, 1993). Moreover, water interception by leaves of broad-leaved plants creates uneven water distribution in overhead systems (Landis and Wilkinson, 2004). Subirrigation could serve as a viable alternative to overhead systems for container seedling propagation of temperate deciduous forest tree species. This is because subirrigation averts potential waste of water, leaching losses, and uneven water distribution associated with overhead systems (Morvant et al.,

\footnotetext{
Received for publication 4 Aug. 2008. Accepted for publication 27 Aug. 2008.

This research was funded by the Fred M. van Eck Forestry Foundation, USDA Forest Service State and Private Forestry, and the Hardwood Tree Improvement and Regeneration Center at Purdue University.

A. Davis, K. Dumroese, M. Gauthier, R. Goodman, M. Mickelbart, R. Morrissey, R. Overton, J. Sloan, and L. Worthen provided consultation and/or manuscript editing. Anonymous reviewers provided useful appraisals of previous versions of our manuscript.

${ }^{1}$ To whom reprint requests should be addressed; e-mail djacobs@purdue.edu
}

2001). For example, subirrigation may conserve $\approx 58 \%$ to $70 \%$ of irrigation water (Dumroese et al., 2006; Landis and Wilkinson, 2004) and promote plant growth at reduced nutrient applications ( $50 \%$ to $70 \%$ ) compared with overhead systems (Beeson and Knox, 1991; Pinto et al., 2008). Additionally, subirrigation may reduce water consumption without jeopardizing plant quality (Cox, 2001; Davis et al., 2008; Elliot, 1990; Santamaria et al., 2003; Yeh et al., 2004).

Fertility management is another imporaffect nutrient availability such as cation exchange capacity, electrical conductivity (EC), and $\mathrm{pH}$ must be maintained at proper levels for optimal plant growth (Jacobs and Timmer, 2005; Timmer and Teng, 2004). Elevated EC at the top of containers in subirrigation systems is associated with fertilizer buildup in the growing medium (Cox, 2001; Richards and Reed, 2004; Van Iersel, 1999). Media pH may decrease at higher fertility, especially with application of ammonium (Kang et al., 2004). Moreover, inadequate nutrient supply in nursery systems may result in some nutritional disorders such as visual discoloration, cessation, and/or decreased growth (Duryea, 1984). Incorporation of controlled-release fertilizers (CRFs) into media (Jacobs and Timmer, 2005; Landis et al., 1989) may minimize elevated tant aspect of nursery production. Factors that
EC and/or potential leaching losses (Landis et al., 1989) and nutrient runoff compared with fertigation with readily available nutrients. Media composition is another important factor that may influence plant growth in subirrigation systems. Substrates with $60 \%$ sphagnum peat were shown to provide the best capillary rise and growth of privet (Ligustrum sp. L.) and viburnum (Viburnum L.) (Caron et al., 2005). Similarly, substrate composition was found to influence EC in the culture of Egyptian starcluster [Pentas lanceloata (Forssk) Deflers] and Philodendron sp. Schott (Klock-Moore and Broschat, 2001).

One potential problem in subirrigation systems is fertilizer salt buildup in media resulting from repeated use of recycled water (Klock-Moore and Broschat, 2001). Salt buildup may affect plants in numerous ways, including changing soil permeability, water and nutrient availability, and direct ion toxicity (Jacobs and Timmer, 2005; Landis et al., 1989). Therefore, it is important to critically evaluate impacts of subirrigation systems on media chemistry and plant growth before adapting this approach in operational container nursery production of tree seedlings.

Our study objectives were to determine whether 1) subirrigation could serve as a viable alternative to conventional overhead watering systems by promoting growth and nutrition of container red oak seedlings; 2) fertilization would modify media chemistry to benefit red oak seedling growth and nutrition; 3) media composition has significant impacts on red oak seedling growth; and 4) subirrigation, nursery fertilization, and media composition promote early field performance of red oak seedlings. Red oak is selected for this study because of its economic importance and increased use in conservation plantings (Jacobs et al., 2004).

\section{Materials and Methods}

Nursery growth and nutrition. Stratified northern red oak seeds from a single mother tree (i.e., open-pollinated half-sib) on the Purdue University campus, West Lafayette, IN (lat. $40^{\circ} 25^{\prime} \mathrm{N}$, long. $86^{\circ} 55^{\prime} \mathrm{W}$ ) were placed under burlap in mist rooms at the Department of Horticulture and Landscape Architecture Plant Growth Facility until a radicle emerged. Seeds were removed from the mist room and stored in a cooler until enough germinated seeds were ready to begin treatments in $\approx 2$ weeks. Germinated acorns were sown into containers $\left(215\right.$ cells $\left./ \mathrm{m}^{2}\right)$ of $656-\mathrm{cm}^{3}$ volume and dimensions of $6.4 \mathrm{~cm} \times$ $25 \mathrm{~cm}$ (diameter $\times$ length) (D40 Deepot, Stuewe and Sons, Corvallis, OR) and filled with soilless media mix. On 15 May 2006, trays of seedlings were placed in a greenhouse with mean day/night temperature of $24 / 20{ }^{\circ} \mathrm{C}$ under ambient light conditions. Until shoots emerged, all containers were kept at container capacity by daily overhead irrigation. Irrigation treatments were initiated on 1 June 2006 using $1.22 \mathrm{~m} \times 1.22-\mathrm{m}$ subirrigation trays (Spencer-Lemaire, Edmonton, 
Alberta, Canada) with a 208-L water reservoir (Mid-West Grow Master, St. Charles, IL) connected to a submersible pump and timer.

Experimental treatments and design. The study tested irrigation methods at two levels (subirrigation versus overhead), fertility at two levels ( 0 versus $1.2 \mathrm{~g}$ nitrogen/plant), and media composition at three levels. The fertilizer treatment consisted of incorporation of CRF (Osmocote Plus 5-6 months release $15 \mathrm{~N}-9 \mathrm{P}-12 \mathrm{~K}$ with micronutrients; Scotts Co., Marysville, $\mathrm{OH}$ ) at the time of media mixing. The media treatments were mixed as a percentage by volume (sphagnum peat: perlite); they were 40:60; 60:40, and 80:20. The experimental design was a split-plot design with the irrigation method serving as the main plot factor and fertility and media as subplot factors. Forty seedlings were grown in each media $\times$ fertilizer treatment combination and each irrigation treatment was replicated three times (three separate subirrigation trays). Plants were watered based on container weights as detailed in Landis et al. (1989). Containers were weighed at saturation every 4 weeks to account for weight of new growth and seedlings were irrigated when containers weighed $75 \pm 5 \%$ of saturated weight. Irrigation was required every 4 to $5 \mathrm{~d}$ during initial seedling establishment and every 2 to $3 \mathrm{~d}$ during the remainder of the growing period. Each container was watered individually to account for the differing drying rates of each media/ fertility combination. Plants were rotated biweekly within benches to minimize edge effects.

Plant sampling, chemical and statistical analysis. Plants were destructively sampled 4 months after irrigation treatments were initiated. After measuring shoot height and root collar diameter, harvested plants were partitioned into leaves, shoots, and roots and dried at $68{ }^{\circ} \mathrm{C}$ for $72 \mathrm{~h}$ for dry weight determination. Leaf area was also measured. Roots were divided into three zones according to soil depth ( 0 to $5 \mathrm{~cm}, 5$ to $15 \mathrm{~cm}$, and 15 to $25 \mathrm{~cm})$. Media collected after destructive sampling was also processed based on these soil depths. Saturated media extracts followed methods described by Warncke (1986). EC and $\mathrm{pH}$ were measured on extracted soil solutions using a Field Scout EC meter (Spectrum Technologies, Inc., Plainfield, IL) and the Accumet $950 \mathrm{pH} /$ ion Meter (Fisher Scientific, Pittsburgh, PA). Dried plant material was milled for chemical analysis, which was conducted by A \& L Great Lakes Laboratories, Inc. (Fort Wayne, IN) using the Association of Official Analytical Chemist (AOAC) methods. Total nitrogen (N) was determined by the combustion ("Dumas") procedure (AOAC 968.06) using a LECO nitrogen analyzer (LECO Corporation, St. Joseph, MI). Additionally, plant samples were digested in nitric + perchloric acids (AOAC 935.13) and phosphorus (P) and potassium $(\mathrm{K})$ determined using inductively coupled argon plasma analysis (AOAC 985.01). Analysis of variance was conducted on growth and nutritional data using SAS software (SAS Institute Inc., Cary, NC). Where not indicated, significant treatment means at $P<0.05$ were ranked according to Tukey's honestly significant difference (HSD) test at $\alpha=0.05$. The remaining seedlings were moved out of the greenhouse into an outdoor-constructed lathe house with shadecloth on 15 Sept. 2006 to harden-off for 1 month in preparation for overwinter storage. Watering was reduced to about once every $5 \mathrm{~d}$, although seedlings were exposed to periodic rains until hardened seedlings were stored overwinter in a dome cooler at $\approx 2$ to

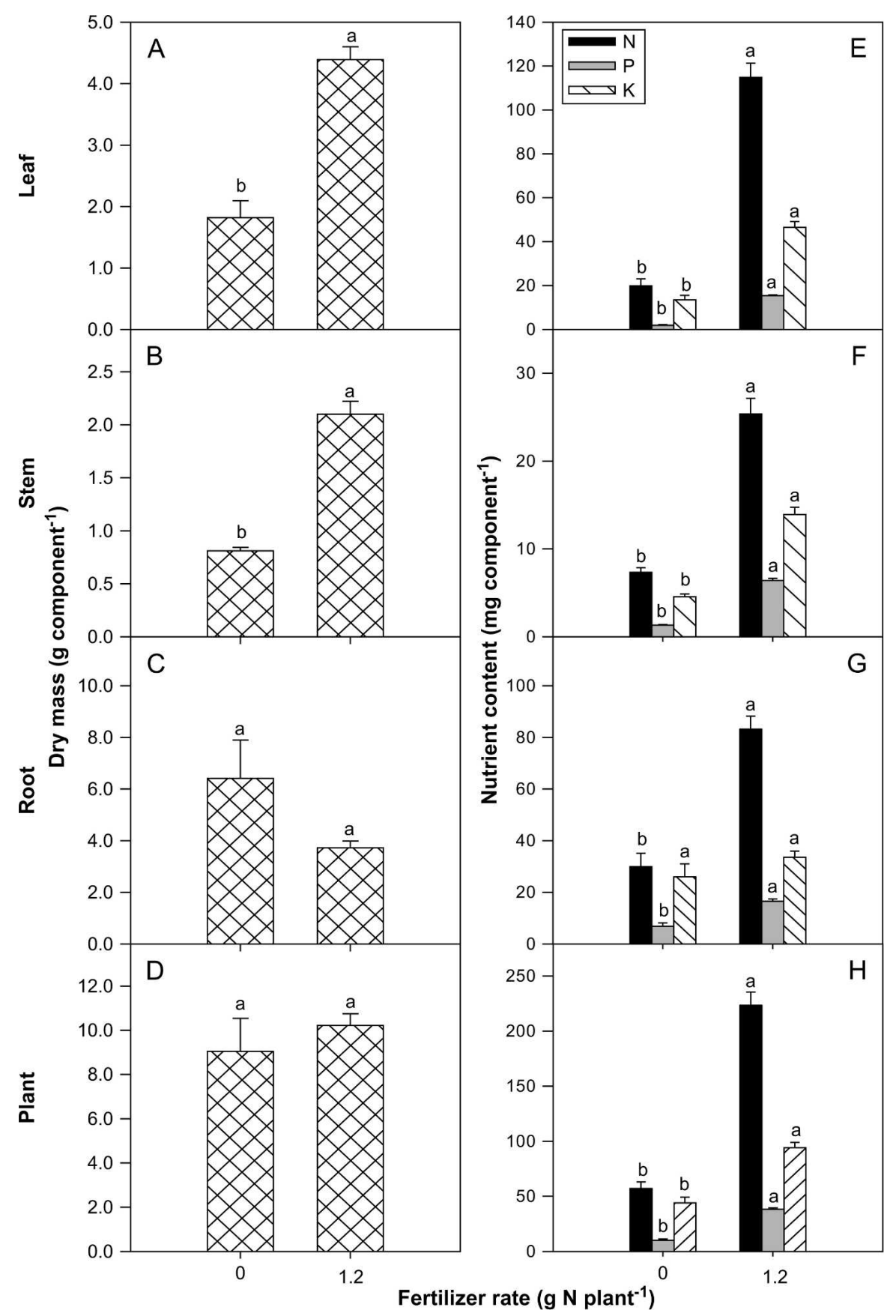

Fig. 1. Effects of fertilizer rate on red oak component dry weight $(\mathbf{A}-\mathbf{D})$ and nutrient content $(\mathbf{E}-\mathbf{H})$ sampled 4 months after sowing under controlled greenhouse environments. Treatments marked with different letters are statistically different according to Tukey's honestly significant difference test at $\alpha=0.05$.
$4{ }^{\circ} \mathrm{C}$. Plants remained in containers throughout the hardening and storage periods.

Field survival and growth. Plants were removed from cooler storage on 15 May 2007 for the field study. Seedlings were removed from containers and placed into moist sawdust $1 \mathrm{~d}$ before planting for easy access at the planting site. A sample of five seedlings per treatment combination (two irrigation $\times$ three media $\times$ two fertility $=12$ treatments) were randomly allocated and planted in 12 rows within a block (one row per treatment). Seedlings were planted mechanically using a tractor-hauled coulter with trencher and 
packing wheels. Seedlings were planted $1.3 \mathrm{~m}$ apart within rows and rows were $2.0 \mathrm{~m}$ apart. This planting scheme was replicated in six blocks at the Purdue University Martell Forest (lat. $40^{\circ} 27^{\prime} \mathrm{N}$, long. $87^{\circ} 1^{\prime} \mathrm{W}$ ) in a former agricultural field, which had been plowed and treated with $2 \%$ RoundUp ${ }^{\circledR}$ (Monsanto Company, Marysville, $\mathrm{OH}$ ) 1 week before planting. Two weeks after planting, an additional treatment of 0.005 $\mathrm{mL} \cdot \mathrm{m}^{-2}$ DuPont Oust XP (Wilmington, DE) and $0.70 \mathrm{~mL} \cdot \mathrm{m}^{-2}$ Pendulum Aquacap (BASF Corporation, Research Triangle Park, NC) was applied to the field. Seedling shoot height and root collar diameter (RCD) were measured after planting. On 13 Sept. 2007, seedling survival, RCD, and shoot height were remeasured. Analysis of variance was conducted to evaluate survival and growth across treatments. SAS software (SAS Institute Inc.) was used for statistical data analysis. Significant treatment means $(P<0.05)$ were ranked according to Tukey's HSD test at $\alpha=0.05$.

\section{Results}

Nursery growth and nutrition. Fertilization, irrigation, and their interaction effects on seedling performance are presented in Figures 1, 2, and 3, respectively. Media composition had no effect on plant dry weight or nutrient content (data not presented). There was a significant fertilizer $\times$ irrigation interaction effect for component $\mathrm{N}$ (Fig. 3; Table 1). For instance, unfertilized plants performed similarly irrespective of irrigation treatments. However, fertilized plants (1.2 g N/plant) that were subirrigated had higher $\mathrm{N}$ contents than those that received overhead irrigation.

Subirrigated seedlings exhibited significant increases in leaf (Fig. 2A) and stem (Fig. 2B) dry weight compared with overheadirrigated plants. However, subirrigation effects were nonsignificant for component tissue nutrient concentration (Table 2). By contrast, subirrigation increased component nutrient content (Fig. 2E-H; Table 1). For example, subirrigation increased leaf $\mathrm{N}$ (41\%), P (5\%), and K (40\%) content compared with overhead irrigation (Fig. 2E). Fertilization significantly affected component dry weight for leaf (Fig. 1A) and stem (Fig. 1B; Table 1). For instance, leaf dry weight increased by $141 \%$ in fertilized relative to unfertilized plants (Fig. 1A). Fertilization significantly altered component tissue nutrient concentration (Table 2). Similarly, fertilization increased component $\mathrm{N}, \mathrm{P}$, and $\mathrm{K}$ contents (Fig. 1E-H; Table 1). Compared with unfertilized plants, leaf nutrient content increased for $\mathrm{N}(475 \%), \mathrm{P}(716 \%)$, and $\mathrm{K}(245 \%)$ in fertilized seedlings (Fig. 1E).

Although root dry weight was lower in fertilized compared with unfertilized seedlings (Fig. 4A; Table 1), N uptake increased $369 \%$ in fertilized plants (Fig. 4B). Root dry weight (Fig. 4C) and $\mathrm{N}$ content (Fig. 4D) were higher in the top soil layers but significantly decreased with depth. For example,

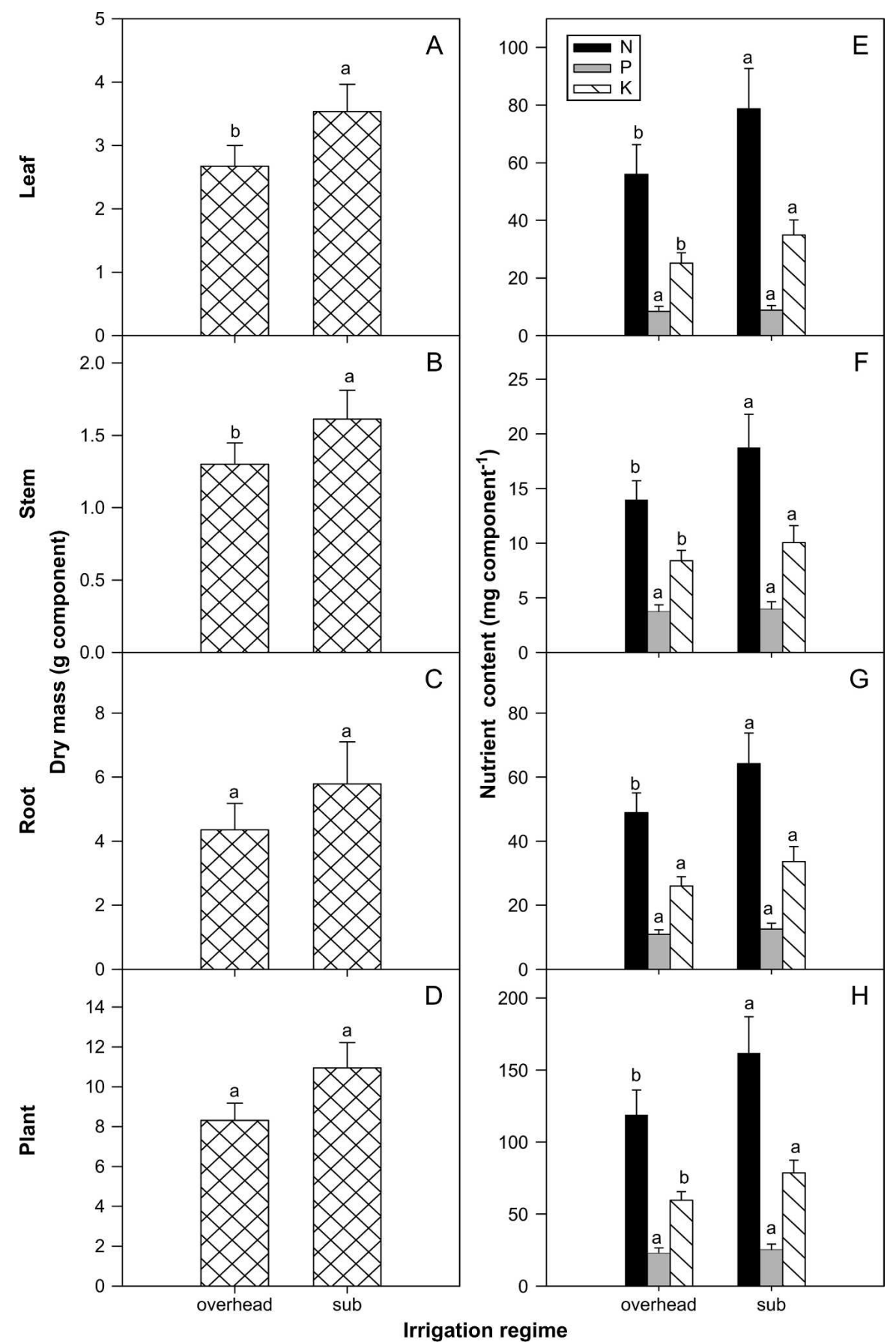

Fig. 2. Effects of irrigation method on red oak component dry weight (A-D) and nutrient content (E-H) sampled 4 months after sowing under controlled greenhouse environments. Treatments marked with different letters are statistically different according to Tukey's honestly significant difference test at $\alpha=0.05$.

compared with the bottom layer (15 to 25 $\mathrm{cm})$, root dry weight increased by $183 \%$ in the top soil $(0$ to $5 \mathrm{~cm}$ ) (Fig. $4 \mathrm{C})$. Similar comparisons showed that root $\mathrm{N}$ content increased by $182 \%$ in top soil relative to the bottom layer (Fig. 4D). Additionally, shoot: root differed significantly with fertilized seedlings having a shoot:root three times higher than controls (data not shown). No significant effects were noted for shoot height, $\mathrm{RCD}$, or leaf area for irrigation or media treatments (data not presented). By contrast, fertilization significantly influenced these parameters (Fig. 5A-C). For example, leaf area increased $204 \%$ in fertilized compared with unfertilized plants (Fig. 5A).

Effects of treatments on soil chemistry. There was no significant media $\times$ fertilizer $\times$ irrigation interaction effects on media EC. However, addition of fertilizer increased media EC (Fig. 6A) and pH (Fig. 6B) in all three soil layers with the top soil recording higher indices. The top soil layers had higher EC in subirrigated than in overhead-irrigated 


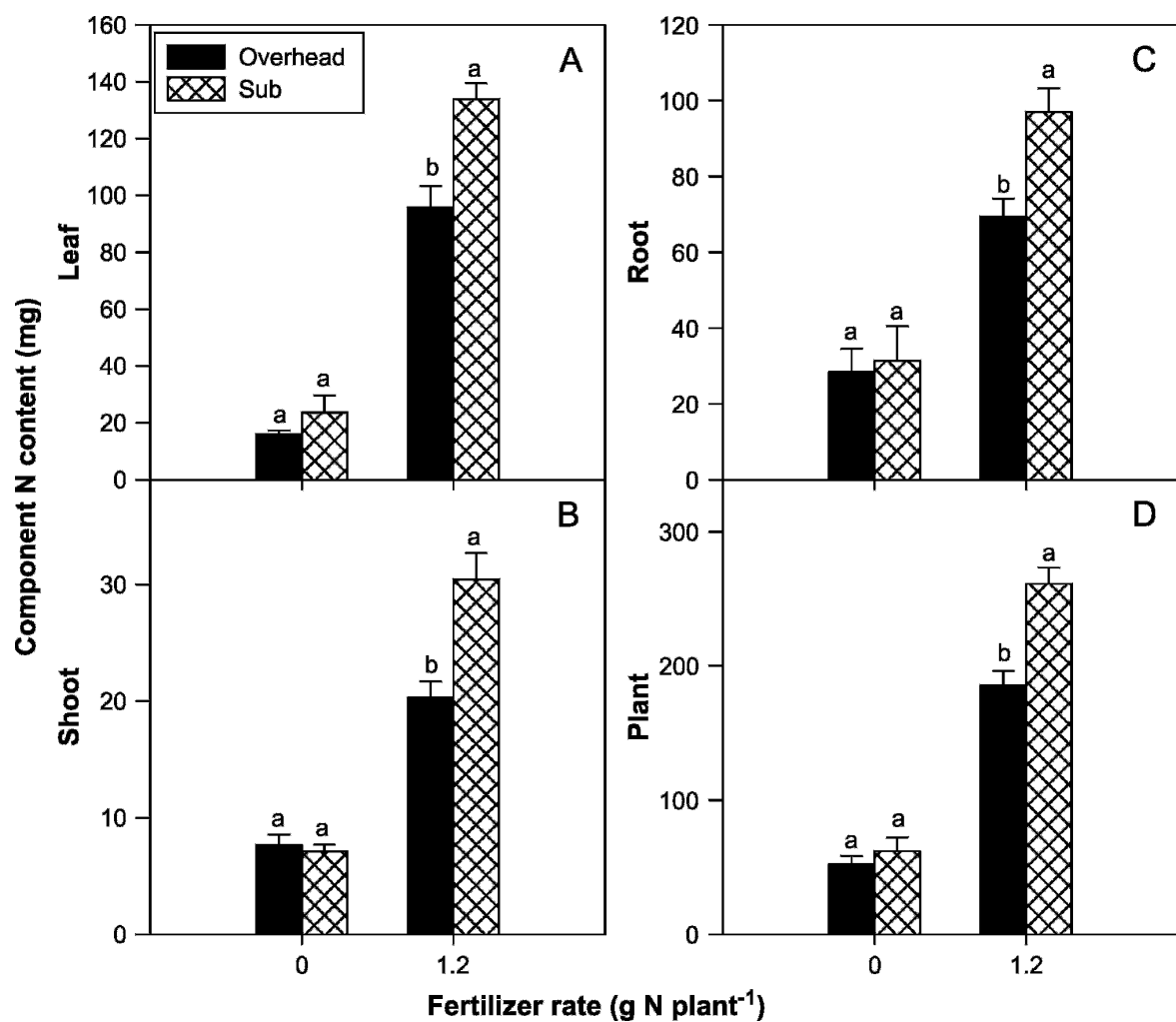

Fig. 3. Fertilizer $\times$ irrigation interaction effects on red oak seedling component nitrogen content sampled 4 months after sowing under controlled greenhouse environments. Treatments marked with different letters are statistically different according to Tukey's honestly significant difference test at $\alpha=0.05$.

systems (Fig. 6C). By contrast, the bottom soil layer had lower EC and higher $\mathrm{pH}$ in subirrigated than in overhead systems (Fig. 6D). Media showed no significant treatment effects on EC, except that EC of the middle layer within the 80:20 mix was slightly higher than that observed within the 60:40 mix (Fig. 6E). Generally, media composition did not significantly affect $\mathrm{EC}$ or $\mathrm{pH}$ except for $\mathrm{pH}$ of the 60:40 and 80:20 mix (Fig. 6F).

Field survival and growth. Irrespective of irrigation type, plants were morphologically similar at planting. However, subirrigation significantly promoted first-year field RCD growth by $16 \%$ compared with overhead systems. Compared with unfertilized seedlings, nursery fertilization decreased early field survival by $28 \%$ and height growth by $16 \%$ (Table 3). Seedling shoot:root was $152 \%$ greater in fertilized relative to unfertilized plants at planting (Table 3 ). However, shoot:RCD was similar across all treatments by the end of Year 1 growth in the field. Media composition had no effect on field response (Table 3 ).

\section{Discussion}

Nursery growth and nutrition. Improved plant performance observed with subirriga- tion versus overhead systems (Figs. 2, 3, and 6 ; Table 2) suggests subirrigation could serve as a viable alternative to conventional overhead systems in nursery culture of temperate deciduous forest tree seedlings. Other studies using subirrigation as a propagation system for hardwood species show results consistent with our findings. For instance, subirrigation was successfully used to propagate black walnut (Juglans nigra L.), bur oak (Quercus macrocarpa L.), swamp white oak $(Q$. bicolor $\mathrm{L}$.), and northern red oak $(Q$. rubra L.) (Coggeshall and Van Sambeek, 2001). By contrast, Davis et al. (2008) reported no differences in morphology of subirrigated versus overhead-irrigated northern red oak seedlings, although propagation was limited to $57 \mathrm{~d}$. Subirrigation apparently holds promise for container hardwood seedling nursery production; however, we recommend further testing and refinement of the system before operational application. For example, we noticed algae buildup in the water reservoirs within the first 6 weeks of our study, which could pose problems in subirrigation tanks if not properly treated. We suggest using an algaecide within the tanks that does not negatively affect media chemical characteristics.

Although the current study showed no effects of media composition on red oak growth parameters, other studies indicate the contrary (Salifu et al., 2006). This result may have been associated with use of only peat and perlite; addition of other components such as coconut coir and/or pine bark may alter media chemistry to positively affect plant growth (Salifu et al., 2006). As expected, fertilization increased dry weight in all plant parts except for roots (Fig. 1). The greater root dry weight but lower $\mathrm{N}$ content in unfertilized seedlings (Fig. 4A-B) demonstrates a classic plant response to nutrient stress. Under $\mathrm{N}$ limitations, plants allocate more resources to root growth and extension, which enables greater soil exploitation for growth resources. Decreased root dry weight after fertilization has been similarly noted for Chinese fir [Cunninghamia lanceolata (Lamb.) Hook] (Xu and Timmer, 1999), Eucalyptus grandis (Cromer and Jarvis,

Table 1. Summary of analysis of variance $(P>\mathrm{F})$ testing effects of irrigation, media, fertility, and their interactions on red oak seedling component dry weight and tissue nutrient content. ${ }^{\mathrm{z}}$

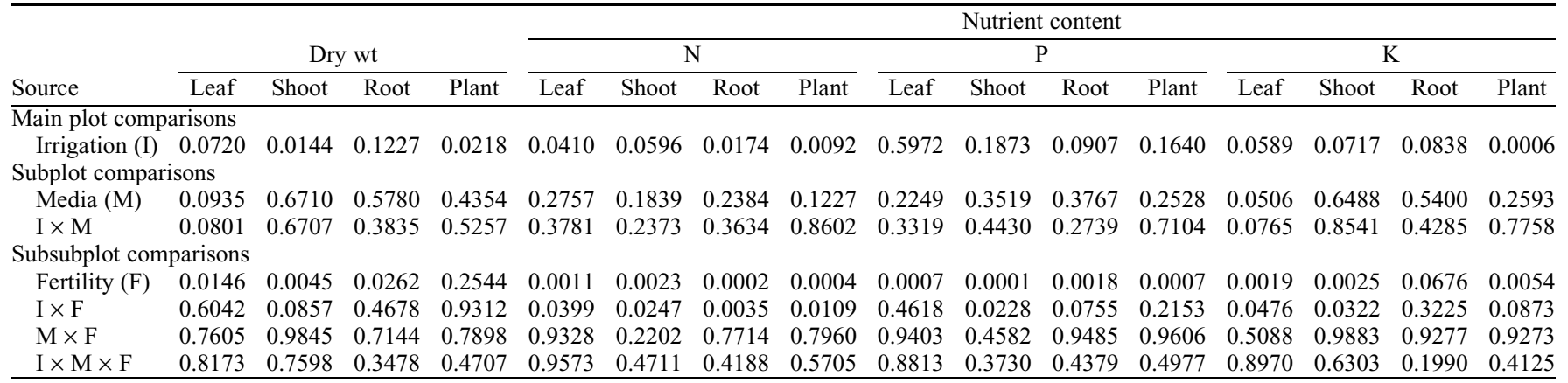

${ }^{2}$ Plants were grown under controlled greenhouse environments for 4 months.

$\mathrm{N}=$ nitrogen; $\mathrm{P}=$ phosphorus; $\mathrm{K}=$ potassium. 
Table 2. Main effects of irrigation, media, and fertility on red oak seedling component nutrient concentration and associated $P>\mathrm{F}$.

\begin{tabular}{|c|c|c|c|c|c|c|c|c|c|c|c|c|}
\hline \multirow{2}{*}{ Source } & \multicolumn{12}{|c|}{ Nutrient concn $\left(\mathrm{g} \cdot \mathrm{kg}^{-1}\right)$} \\
\hline & \multicolumn{4}{|c|}{$\mathrm{N}$} & \multicolumn{4}{|c|}{$\mathrm{P}$} & \multicolumn{4}{|c|}{$\mathrm{K}$} \\
\hline \multicolumn{13}{|l|}{ Irrigation } \\
\hline Subirrigation & $19.10 \mathrm{a}$ & $10.69 \mathrm{a}$ & $13.98 \mathrm{a}$ & $14.59 \mathrm{a}$ & $2.07 \mathrm{~b}$ & $2.19 \mathrm{a}$ & $2.70 \mathrm{a}$ & $2.28 \mathrm{~b}$ & $9.08 \mathrm{a}$ & $5.84 \mathrm{a}$ & $6.62 \mathrm{a}$ & $7.18 \mathrm{a}$ \\
\hline \multicolumn{13}{|l|}{ Media } \\
\hline $40: 60$ & $17.76 \mathrm{a}$ & $9.80 \mathrm{a}$ & $12.90 \mathrm{a}$ & $13.38 \mathrm{a}$ & $2.17 \mathrm{a}$ & $2.22 \mathrm{a}$ & $2.63 \mathrm{a}$ & $2.30 \mathrm{a}$ & $8.86 \mathrm{a}$ & $5.67 \mathrm{a}$ & $6.23 \mathrm{a}$ & $6.86 \mathrm{a}$ \\
\hline $60: 40$ & $19.53 \mathrm{a}$ & $11.35 \mathrm{a}$ & $14.54 \mathrm{a}$ & $15.29 \mathrm{a}$ & $2.43 \mathrm{a}$ & $2.56 \mathrm{a}$ & $2.86 \mathrm{a}$ & $2.59 \mathrm{a}$ & $9.37 \mathrm{a}$ & $6.72 \mathrm{a}$ & $6.91 \mathrm{a}$ & $7.46 \mathrm{a}$ \\
\hline 0 (g N/plant) & $10.95 \mathrm{~b}$ & $9.34 \mathrm{~b}$ & $5.16 \mathrm{~b}$ & $6.95 \mathrm{~b}$ & $1.02 \mathrm{~b}$ & $1.66 \mathrm{~b}$ & $1.12 \mathrm{~b}$ & $1.17 \mathrm{~b}$ & $7.52 \mathrm{~b}$ & $5.70 \mathrm{a}$ & $4.33 \mathrm{~b}$ & $5.22 \mathrm{~b}$ \\
\hline 1.2 (g N/plant) & $26.08 \mathrm{a}$ & $12.12 \mathrm{a}$ & $22.98 \mathrm{a}$ & $21.97 \mathrm{a}$ & $3.59 \mathrm{a}$ & $3.16 \mathrm{a}$ & $4.64 \mathrm{a}$ & $3.85 \mathrm{a}$ & $10.58 \mathrm{a}$ & $6.70 \mathrm{a}$ & $9.11 \mathrm{a}$ & $9.24 \mathrm{a}$ \\
\hline \multicolumn{13}{|c|}{ Analysis of variance $P>\mathrm{F}$} \\
\hline Irrigation & 0.0565 & 0.9115 & 0.8257 & 0.6846 & 0.0070 & 0.0924 & 0.2138 & 0.0424 & 0.8678 & 0.2146 & 0.6131 & 0.5099 \\
\hline Media & 0.1653 & 0.3464 & 0.2457 & 0.0927 & 0.1100 & 0.2877 & 0.1184 & 0.0596 & 0.5536 & 0.1524 & 0.2479 & 0.3091 \\
\hline Fertility & 0.0025 & 0.0387 & 0.0027 & 0.0025 & 0.0021 & 0.0182 & 0.0031 & 0.0033 & 0.0089 & 0.2120 & 0.0046 & 0.0062 \\
\hline
\end{tabular}

Column means followed by different letters within a given treatment differ significantly according to Tukey's honestly significant difference test at $\alpha=0.05$ $\mathrm{N}=$ nitrogen; $\mathrm{P}=$ phosphorus; $\mathrm{K}=$ potassium.
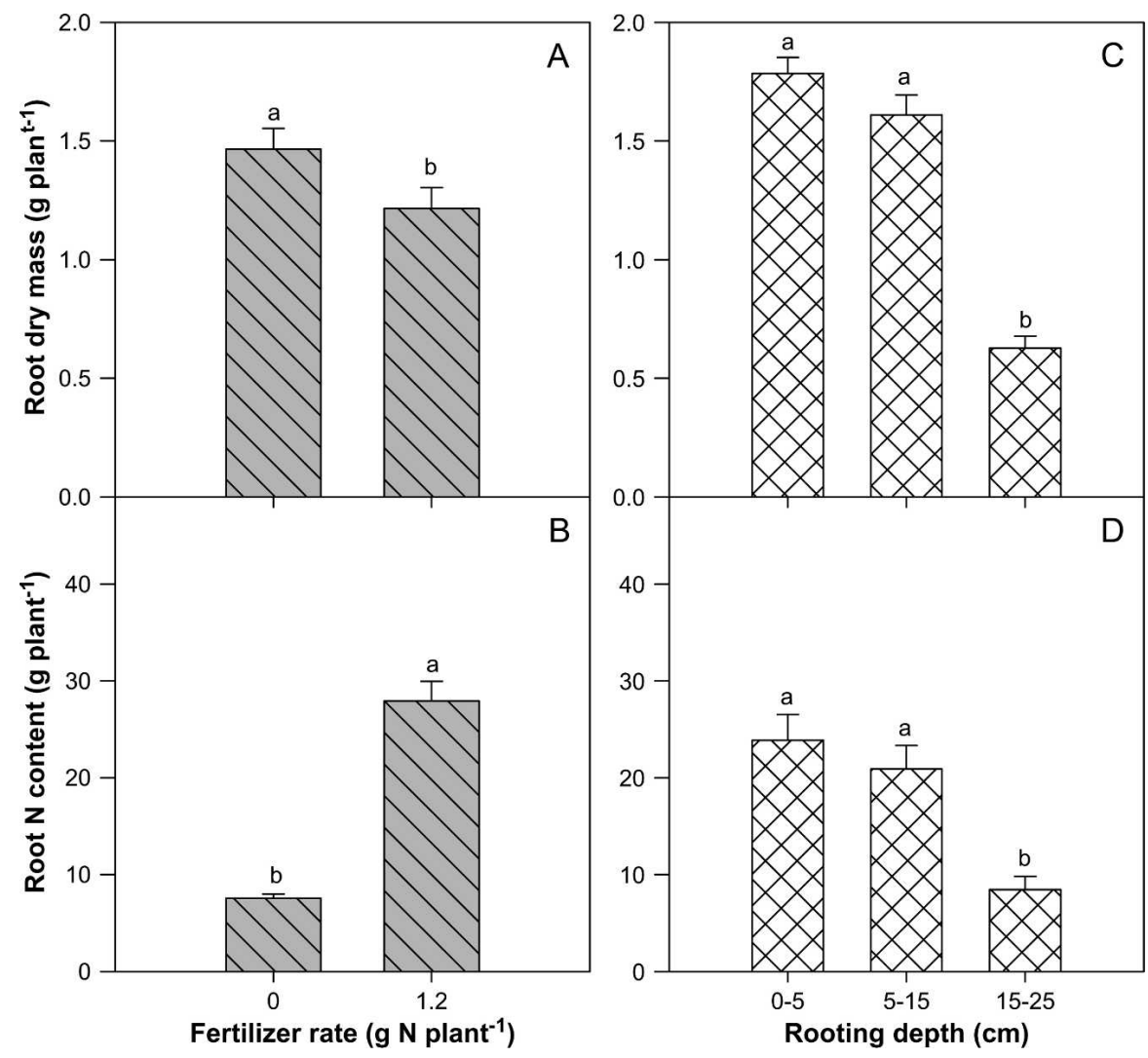

Fig. 4. Effects of fertilizer rate and root depth on root dry weight and nitrogen content at final harvest. Treatments marked with different letters are statistically different according to Tukey's honestly significant difference test at $\alpha=0.05$.

1990), and several hardwood species (Canham et al., 1996). This reduction in root mass contributed to the higher shoot:root observed in fertilized seedlings (Fig. 1). Greater $\mathrm{N}$ uptake at lower versus upper soil depths agrees with results of other studies (Goransson et al., 2007). This supports the contention that fine roots in shallow soil layers may be specialized for nutrient uptake (Goransson et al., 2007). Alternatively, greater $\mathrm{N}$ uptake at upper soil depths may be explained by the high media fertility (Fig. 6A) and greater root dry weight therein.

Effects of treatments on soil chemistry. One potential disadvantage of subirrigation is fertilizer salt buildup in substrates (Barrett, 1991). In our study, substrate EC increased with addition of fertilizer and for subirrigated compared with overhead-irrigated plants as noted by others (Davis et al., 2008; KlockMoore and Broschat, 2001; Yeh et al., 2004).

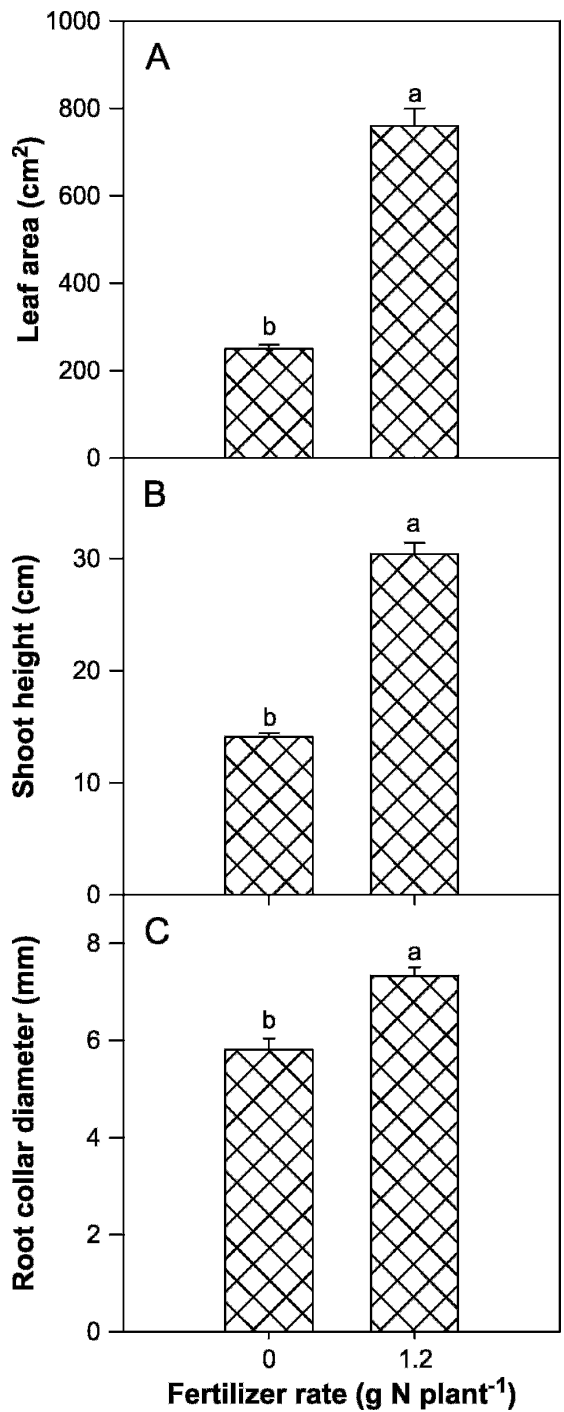

Fig. 5. Effects of fertilizer rate on red oak leaf area (A), shoot height (B), and root collar diameter (C) sampled 4 months after sowing under controlled greenhouse environments. Treatments marked with different letters are statistically different according to Tukey's honestly significant difference test at $\alpha=0.05$. 

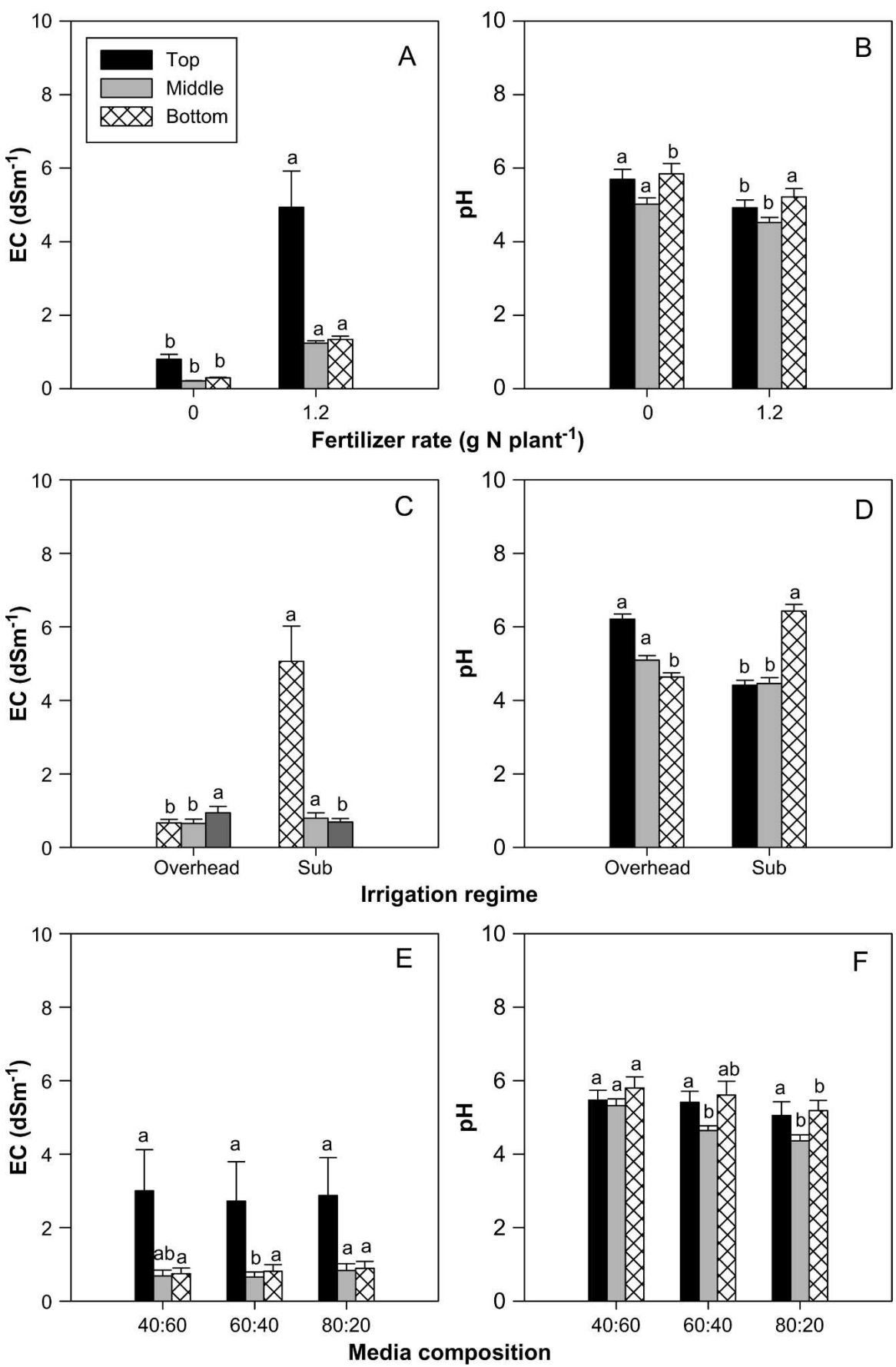

Fig. 6. Media chemistry as affected by fertilizer addition (A-B), irrigation method (C-D), and media composition (E-F) sampled 4 months after sowing under controlled greenhouse environments. Treatments marked with different letters are statistically different according to Tukey's honestly significant difference test at $\alpha=0.05$.

This is especially true for the upper soil layers where EC was $5 \mathrm{dS} \cdot \mathrm{m}^{-1}$ greater with subirrigation than for overhead systems (Fig. 6). Similarly, higher EC was recorded in media of subirrigation compared with overhead systems (Davis et al., 2008; Morvant et al., 1997). This has potential to decrease plant growth with eventual mortality. Although suggested optimal EC levels in container systems may range from 2.0 to $3.5 \mathrm{dS} \cdot \mathrm{m}^{-1}$ (Jacobs and Timmer, 2005; Timmer and Teng, 2004; Warncke and Krauskopf,
1983), no detrimental effects were noted in our study when EC exceeded these recommendations. The $\mathrm{pH}$ in subirrigated seedlings dropped below 4.5 in the top two soil layers but was $\approx 6.5$ in the bottom soil layer. This contrasts with results noted by Morvant et al. (1997) in which pH was lowest in the bottom soil layer of media in an ebb and flood irrigation system.

Field survival and growth. Improved field performance with subirrigation versus overhead systems suggests the former system can serve as a viable alternative for propagating hardwood container stock for outplanting. Lower field survival and growth noted with nursery fertilization contrast markedly with improved field responses often observed after nutritional conditioning at the nursery stage (Salifu et al., 2008). The mechanism(s) to explain the reduced early field survival and growth of fertilized plants under our subirrigation system is not clear without additional physiological or environmental data and needs further investigation. However, several factors may explain such a response. First, increased transpiration associated with greater shoots and larger leaf area in fertilized plants could partly explain reduced growth owing to moisture uptake not meeting transpiration demand soon after transplanting. Second, herbicide application after flushing may have negatively affected plants and could partly explain reduced growth. Increased relative growth allocation to roots during the nursery stage (Figs. $1 \mathrm{C}$ and 4A) may have conferred early outplanting success in unfertilized plants. Additionally, greater root mass in unfertilized plants may be associated with increased carbohydrate reserves, which could have been relied on immediately after planting to enhance survival and growth. Furthermore, greater root mass will allow for increased root-soil contact, which enhances resources exploitation. Despite treatment effects, the limited duration of our field trial restricts ability to extrapolate our results to long-term plantation establishment success.

\section{Conclusions}

The current study results suggest that subirrigation can be effectively used to grow northern red oak seedlings in containers with improved growth and morphology compared with that obtained with overhead systems. Additionally, the importance of nutrition at the nursery stage was demonstrated by the rapid plant response to fertilization. However, field survival and height growth were reduced in fertilized compared with unfertilized seedlings, which may have been associated with greater root biomass and decreased shoot:root of nonfertilized seedlings at the time of planting. Alternatively, herbicide application may have negatively affected plant growth, which masked nursery fertilization effects. The need exists to critically examine fertility under subirrigation programs in the nursery in relation to resulting field performance. Varying media composition using only peatmoss versus perlite did not benefit plant growth and nutrition, suggesting that additional components that alter media physical and chemical properties could be beneficial. Compared with overhead systems, our study suggests subirrigation as a viable propagation alternative, yielding equal or better plant growth and nutrition at increased water use efficiency with zero leaching losses. 
Table 3. Main effects of irrigation, media, and fertility on red oak seedling first-year field survival, height, and root collar diameter (RCD) growth.

\begin{tabular}{|c|c|c|c|c|c|c|c|}
\hline \multirow[b]{2}{*}{ Source } & \multirow{2}{*}{$\begin{array}{c}\text { Survival } \\
(\%)\end{array}$} & \multicolumn{3}{|c|}{ Initial } & \multicolumn{2}{|c|}{ Growth } & \multirow{2}{*}{$\begin{array}{c}\text { Final } \\
\text { Shoot:RCD }\end{array}$} \\
\hline & & $\mathrm{Ht}(\mathrm{cm})$ & $\mathrm{RCD}(\mathrm{mm})$ & Shoot:root & $\mathrm{Ht}(\mathrm{cm})$ & $\mathrm{RCD}(\mathrm{mm})$ & \\
\hline \multicolumn{8}{|l|}{ Irrigation } \\
\hline Overhead & $86.7 \mathrm{~A}$ & $21.4 \mathrm{~A}$ & $5.98 \mathrm{~A}$ & $3.50 \mathrm{~A}$ & $23.6 \mathrm{~A}$ & $4.38 \mathrm{~B}$ & $4.22 \mathrm{~A}$ \\
\hline Subirrigation & $82.2 \mathrm{~A}$ & $22.0 \mathrm{~A}$ & $5.94 \mathrm{~A}$ & $3.62 \mathrm{~A}$ & $26.0 \mathrm{~A}$ & $5.06 \mathrm{~A}$ & $4.24 \mathrm{~A}$ \\
\hline \multicolumn{8}{|l|}{ Media } \\
\hline $40: 60$ & $87.5 \mathrm{~A}$ & $21.8 \mathrm{AB}$ & $6.07 \mathrm{~A}$ & $3.52 \mathrm{~A}$ & $24.2 \mathrm{~A}$ & $4.59 \mathrm{~A}$ & $4.24 \mathrm{~A}$ \\
\hline $60: 40$ & $83.3 \mathrm{~A}$ & $22.9 \mathrm{~A}$ & $6.11 \mathrm{~A}$ & $3.66 \mathrm{~A}$ & $27.3 \mathrm{~A}$ & $5.01 \mathrm{~A}$ & $4.35 \mathrm{~A}$ \\
\hline $80: 20$ & $82.5 \mathrm{~A}$ & $20.3 \mathrm{~B}$ & $5.71 \mathrm{~B}$ & $3.51 \mathrm{~A}$ & $22.8 \mathrm{~A}$ & $4.55 \mathrm{~A}$ & $4.10 \mathrm{~A}$ \\
\hline \multicolumn{8}{|l|}{ Fertility } \\
\hline $0(\mathrm{~g} \mathrm{~N} / \mathrm{pla}$ & $98.3 \mathrm{~A}$ & 1 & $5.32 \mathrm{~B}$ & B & $27.0 \mathrm{~A}$ & A & $4.17 \mathrm{~A}$ \\
\hline $1.2(\mathrm{~g} \mathrm{~N} /$ plant $)$ & $70.6 \mathrm{~B}$ & $28.5 \mathrm{~A}$ & $6.61 \mathrm{~A}$ & $4.31 \mathrm{~A}$ & $22.6 \mathrm{~B}$ & $4.79 \mathrm{~A}$ & $4.29 \mathrm{~A}$ \\
\hline \multicolumn{8}{|c|}{ Analysis of variance $P>\mathrm{F}$} \\
\hline Irrigation & 0.2662 & 0.4567 & 0.3213 & 0.3985 & 0.1652 & 0.0427 & 0.8883 \\
\hline Media & 0.5466 & 0.0494 & 0.0043 & 0.6272 & 0.1053 & 0.4441 & 0.4099 \\
\hline Fertility & $<0.0001$ & $<0.0001$ & $<0.0001$ & $<0.0001$ & 0.0126 & 0.6562 & 0.4304 \\
\hline
\end{tabular}

Column means followed by different letters within a given treatment differ significantly according to Tukey's honestly significant difference test at $\alpha=0.05$.

\section{Literature Cited}

Barrett, J. 1991. Water and fertilizer movement in greenhouse subirrigation systems. Greenhouse Manager 10:89-90.

Beeson, R.C. and G.W. Knox. 1991. Analysis of efficiency of overhead irrigation in container production. HortScience 26:848-850.

Canham, C.D., A.R. Berkowitz, V.R. Kelly, G.M. Lovett, S.V. Ollinger, and J. Schnurr. 1996. Biomass allocation and multiple resource limitation in tree seedlings. Can. J. For. Res. 26:1521-1530.

Caron, J., D.E. Elrick, R. Beeson, and J. Boudreau. 2005. Defining critical capillary rise properties for growing media in nurseries. Soil Sci. Soc. Amer. J. 69:794-806.

Coggeshall, M.V. and J.W. Van Sambeek. 2001 Development of a subirrigation system with potential for hardwood tree propagation. Combined Proceedings International Plant Propagators' Soc. 51:443-448.

Cox, D.A. 2001. Growth, nutrient content, and growth medium electrical conductivity of poinsettia irrigated by subirrigation or from overhead. J. Plant Nutr. 24:523-533.

Cromer, R.N. and P.G. Jarvis. 1990. Growth and biomass partitioning in Eucalyptis grandis seedlings in response to nitrogen supply. Aust. J. Plant Physiol. 17:503-515.

Davis, A.S., D.F. Jacobs, R.P. Overton, and R.K. Dumroese. 2008. Influence of irrigation method and container type on Quercus rubra seedling growth and media electrical conductivity. Nat. Plants J. 9:4-13.

Dumroese, R.K., J.R. Pinto, D.F. Jacobs, A.S. Davis, and B. Horiuchi. 2006. Subirrigation reduces water use, nitrogen loss, and moss growth in a container nursery. Nat. Plants J. 7:253-261.

Duryea, M.L. 1984. Nursery cultural practices: Impacts on seedling quality. p. 143-164. In: Duryea, M.L. and T.D. Landis (eds.). Forest nursery manual: Production of bareroot seedlings. Junk Publishers: The Hague/Boston/Lancaster for Forest Research Laboratory, Oregon State University, Corvallis, OR.

Elliot, G. 1990. Reduce water and fertilizer with ebb and flow. Greenhouse Grower 8:70-75.

Goransson, H., A.M. Fransson, and U. JonssonBelyazid. 2007. Do oaks have different strategies for uptake of $\mathrm{N}, \mathrm{K}$, and $\mathrm{P}$ depending on soil depth? Plant Soil 297:119-125.

Jacobs, D.F., A.L. Ross-Davis, and A.S. Davis. 2004. Establishment success of conservation tree plantations in relation to silvicultural practices in Indiana, USA. New For. 28:23-36.

Jacobs, D.F. and V.R. Timmer. 2005. Fertilizerinduced changes in rhizosphere electrical conductivity: Relation to forest tree seedling root system growth and function. New For. 30: 147-166.

Kang, J.G., M. van Iersel, and K. Nemali. 2004. Fertilizer concentration and irrigation method affect growth and fruiting of ornamental pepper. J. Plant Nutr. 27:867-884.

Klock-Moore, K.A. and T.A. Broschat. 2001. Effect of four growing substrates on growth of ornamental plants in two irrigation systems. HortTechnology 11:456-460.

Landis, T.D., R.W. Tinus, S.E. McDonald, and J.P. Barnett. 1989. Seedling nutrition and irrigation, p. 1-67. The container tree nursery manual. Vol. 4. USDA Forest Service Agr. Hdbk. 674.
Landis, T.D. and K. Wilkinson. 2004. Subirrigation: A better option for broad-leaved container nursery crops? USDA Forest Service Forest Nursery Notes. Summer:14-17.

Morvant, J.K., J.M. Dole, and E. Allen. 1997. Irrigation systems alter distribution of roots, soluble salts, nitrogen, and $\mathrm{pH}$ in the root medium. HortTechnology 7:156-160.

Morvant, J.K., J.M. Dole, and J.C. Cole. 2001. Fertilizer source and irrigation system affect geranium growth and nitrogen retention. HortScience 36:1022-1026.

Oka, P. 1993. Surviving water restrictions. Amer. Nurse 178:68-71.

Pinto, J.R., R.A. Chandler, and R.K. Dumroese. 2008. Growth, nitrogen use efficiency, and leachate comparison of subirrigated and overhead irrigated park purple coneflower seedlings. HortScience 43:897-901.

Richards, D.L. and D.W. Reed. 2004. New Guinea impatiens growth response and nutrient release from controlled-release fertilizer in a recirculating subirrigation and top-watering system. HortScience 39:280-286.

Salifu, K.F., D.F. Jacobs, and Z.K.D. Birge. 2008. Nursery nitrogen loading improves field performance of bareroot oak seedlings planted on abandoned mine lands. Restor. Ecol. (in press).

Salifu, K.F., M.A. Nicodemus, D.F. Jacobs, and A.S. Davis. 2006. Evaluating chemical indices of growing media for nursery production of Quercus rubra seedlings. HortScience 41:1342-1346.

Santamaria, P., G. Campanile, A. Parente, and A. Elia. 2003. Subirrigation vs. drip-irrigation: Effects on yield and quality of soilless grown cherry tomato. J. Hort. Sci. Biotechnol. 78: 290-296.

Timmer, V.R. and Y. Teng. 2004. Pre-transplant fertilization of containerized Picea mariana seedlings: Calibration and bioassay growth response. Can. J. For. Res. 34:2089-2098.

Van Iersel, M. 1999. Fertilizer concentration affects growth and nutrient composition of subirrigated pansies. HortScience 34:660-663.

Warncke, D.D. and D.M. Krauskopf. 1983. Greenhouse growth media: Testing and nutritional guidelines. Michigan State Univ. Coop. Ext. Serv. Bul. E-1736.

Warncke, D.D. 1986. Analyzing greenhouse growth media by the saturation extract method. HortScience 21:223-225.

Xu, X. and V.R. Timmer. 1999. Growth and nitrogen nutrition of Chinese fir seedlings exposed to nutrient loading and fertilization. Plant Soil 216:83-91.

Yeh, D.M., P.H. Hsu, and J.G. Atherton. 2004 Growth and flowering responses of Canna X generalis to nitrogen supplied to the growing medium via top- or subirrigation. J. Hort. Sci. Biotechnol. 79:511-514. 